\title{
Knockdown of PLC-gamma-2 and calmodulin 1 genes sensitizes human cervical adenocarcinoma cells to doxorubicin and paclitaxel
}

\author{
Anthony Stanislaus ${ }^{1}$, Athirah Bakhtiar ${ }^{1}$, Diyana Salleh', Snigdha Tiash², Tahereh Fatemian², Sharif Hossain ${ }^{3}$, \\ Toshihiro Akaike $^{3}$ and Ezharul Hoque Chowdhury ${ }^{2,3^{*}}$
}

\begin{abstract}
Background: RNA interference (RNAi) is a powerful approach in functional genomics to selectively silence messenger mRNA (mRNA) expression and can be employed to rapidly develop potential novel drugs against a complex disease like cancer. However, naked siRNA being anionic is unable to cross the anionic cell membrane through passive diffusion and therefore, delivery of siRNA remains a major hurdle to overcome before the potential of siRNA technology can fully be exploited in cancer. pH-sensitive carbonate apatite has recently been developed as an efficient tool to deliver siRNA into the mammalian cells by virtue of its high affinity interaction with the siRNA and the desirable size distribution of the resulting siRNA-apatite complex for effective cellular endocytosis. Moreover, internalized siRNA was found to escape from the endosomes in a time-dependent manner and efficiently silence gene expression.
\end{abstract}

Results: Here we show that carbonate apatite-mediated delivery of siRNA against PLC-gamma-2 (PLCG2) and calmodulin 1 (CALM1) genes has led to the sensitization of a human cervical cancer cell line to doxorubicin- and paclitaxel depending on the dosage of the individual drug whereas no such enhancement in cell death was observed with cisplatin irrespective of the dosage following intracellular delivery of the siRNAs.

Conclusion: Thus, PLCG2 and CALM1 genes are two potential targets for gene knockdown in doxorubicin and paclitaxel-based chemotherapy of cervical cancer.

Keywords: Carbonate apatite, Nanoparticle, siRNA, PLC-gamma-2, Calmodulin 1, Cervical cancer, Cisplatin, Doxorubicin, Paclitaxel

\section{Background}

Genes are transcribed into mRNAs and subsequently translated into proteins to carry out the major functions within a cell and the mutations in certain genes leading to their suppression or overexpression are usually responsible for both acquired and genetic diseases. Delivery of functional gene(s) or gene-silencing element(s) could be the potential options in restoring the normal

\footnotetext{
* Correspondence: md.ezharul.hoque@monash.edu

${ }^{2}$ Jeffrey Cheah School of Medicine and Health Sciences, Monash University Sunway Campus, Jalan Lagoon Selatan, Bandar Sunway, Selangor Darul Ehsan, Malaysia

${ }^{3}$ Department of Biomolecular Engineering, Graduate School of Bioscience and Biotechnology, Tokyo Institute of Technology, 4259 Nagatsuta-cho, Midori-ku, Yokohama 226-8501, Japan

Full list of author information is available at the end of the article
}

functions of the cell. RNA interference (RNAi) that can selectively silence mRNA expression in cell cytoplasm can be utilized to develop new drugs against target therapeutic genes [1-5]. RNAi can be harnessed for selective gene inhibition in two different routes: 1) cytoplasmic delivery of short interfering RNA (siRNA) for directly breaking down the specific mRNA and 2) nuclear delivery of gene expression cassettes to express a short hairpin RNA (shRNA) which is further processed by cellular machinery to siRNA in the cytoplasm [6]. However, siRNA, a synthetic RNA duplex of 21-23 nucleotides, is more advantageous than shRNA because of the difficulty in the construction of a shRNA expression system [6], and the requirement of the expression system to overcome the nuclear barrier for shRNA 
expression [7]. siRNA in the cytoplasm of the cells incorporates into a multiprotein RNA-induced silencing complex (RISC) and is unwound into single-stranded RNAs by Argonaute 2, a multifunctional protein within the RISC, forming antisense strand-associated RISC in order to guide and selectively degrade the complementary mRNA with the help of Argonaute-2 [8]. Perfect hybridization between the antisense strand of siRNA and the target mRNA leads to degradation of the mRNA near the center of the target-siRNA duplex [8]. However, the strong anionic phosphate backbone with consequential electrostatic repulsion from the anionic cell membrane is an obstacle to the passive diffusion of siRNA across the membrane [9]. The hydrophobic lipid bilayer could pose an additional barrier to the hydrophilic siRNA. Moreover, naked siRNA can be degraded by the plasma nucleases and even subjected to renal elimination due to its small size before reaching the target site in vivo $[10,11]$. A number of existing non-viral vectors have been developed for intracellular siRNA delivery with limited efficacy [8]. Usually, a non-viral vector being cationic can electrostatically bind with an anionic siRNA to form a stable complex, thus protecting it from nuclease-mediated degradation, enabling it to cross the plasma membrane through endocytosis and finally facilitating its endosomal escape [8].

Cancer is a complex disease responsible for millions of deaths worldwide and despite remarkable efforts made in the last decades limited successes have been achieved so far to cure various types of cancer. Clinical efficacy of current chemotherapeutic drugs are often limited owing to to their toxic effects on normal cells and the patients can tolerate only the doses which are therapeutically insufficient, thus leading to chemoresistance and subsequent tumor recurrence [12]. Since cancer is the result of overexpression or suppression of signaling pathways aiding cancer cell survival and proliferation, non-viral vector-mediated delivery of siRNAs specific for the genes of pathways, to cancer cells would be the potential treatment options that might additionally render cancer cells extremely sensitive to cytotoxic chemotherapy [11]. Among the signalling cascades, MAP kinase, PI-3 knase and $\mathrm{Ca}^{2+}$-calmodulin pathways are extensively involved in proliferation and survival of various cancer cells [1315]. On the other hand, conventionally used chemotherapy drugs induce apoptosis of cancer cells by interfering with the major cellular functions which might have some of cross-talk with the components of cell proliferation/ survival pathways. siRNA-mediated knock-down of the genes encoding the enzymes of those pathways, therefore, might not only slow down the growth of cancer cells, but also sensitize them to anti-cancer drugs.

In $\mathrm{Ca}^{2+}$-calmodulin pathway, stimulation with growth factor either $G$ protein-coupled receptors or receptor tyrosine kinases activates the phospholipase C (PLC) enzyme, which, in turn, hydrolyses the membrane phospholipid, phosphatidylinositol 4, 5 bisphosphate (PIP2) to diacylglycerol (DAG) and inositol $(1,4,5)$ trisphosphate (IP3). DAG activates PKC while IP3 binds to its receptor on the endoplasmic reticulum allowing diffusion of $\mathrm{Ca}^{2+}$ from the ER to increase intracellular $\left[\mathrm{Ca}^{2+}\right]$ [16]. The released $\mathrm{Ca}^{2+}$ binds to calmodulin (CaM) and $\mathrm{Ca}^{2+} / \mathrm{CaM}$ functions as an allosteric activator of a considerable number of protein kinases regulating cell proliferation and apoptosis [17].

Recently, we have developed an efficient siRNA delivery system based on some unique properties of carbonate apatite- electrostatic affinity for binding anionic siRNA, ability of preventing crystal growth for generation of nano-size particles for efficient endocytosis and fast dissolution kinetics in endosomal acidic compartments to facilitate the release of siRNA from the particles as well as from the endosomes, leading to the efficient silencing of reporter gene expression. Moreover, nanoparticle-assisted delivery of validated siRNA against cyclin B1 resulted in the significant inhibition of cancer cell growth $[18,19]$.

Here we show that carbonate apatite-mediated delivery of siRNA against PLC-gamma-2 (PLCG2) and calmodulin 1 (CALM1) genes sensitized a human cervical cancer cell line (HeLa cell) to doxorubicin- and paclitaxelinduced cell death depending on the doses of the drugs while no such synergistic effect was observed with cisplatin, another commonly used chemotherapy drugs.

\section{Results and discussion}

Roles of PLCG2 and CALM1 in the proliferation/survival of cervical cancer cells

In order to investigate the potential roles of PLCG2 and CALM1 in the proliferation or survival of HeLa cells that express both of the proteins [20-23], specific validated siRNA $(10 \mathrm{mM})$ against PLCG2 or CALM1 mRNA was added together with $\mathrm{Ca}^{2+}(3 \mathrm{mM})$ to the bicarbonate-buffered DMEM prior to the incubation at $37{ }^{\circ} \mathrm{C}$ for $30 \mathrm{~min}$ to form carbonate apatite/siRNA complexes. Figure 1 shows the cell viability as assessed by MTT assay following consecutive $48 \mathrm{~h}$ incubation of HeLa cells with the apatite complexes carrying either anti-PLCG2 or anti-CALM1 siRNA. Almost $10 \%$ of the cells were killed due to the silencing of either PLCG2 or CALM1 gene expression indicating that PLCG2, an upstream molecule and CALM1, a downstream molecule of $\mathrm{Ca}^{2+}$-calmodulin pathway are critically involved in the proliferation or survival of HeLa cells.

While both of the siRNAs were validated by the manufacturer (QIAGEN) using quantitative RT-PCR to confirm their knockdown efficiency of $82 \%$, the relatively low efficacy of either treatment in killing cancer cells as 


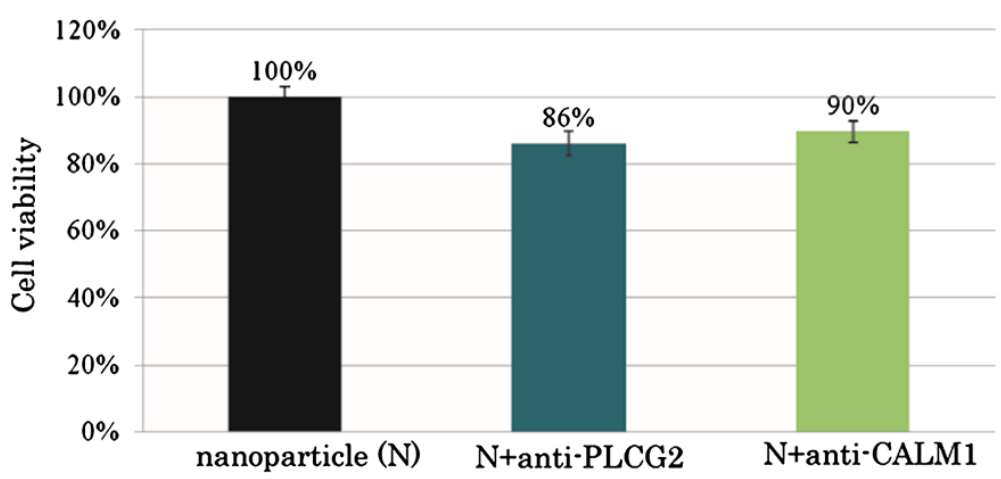

Figure 1 Effects of silencing of PLCG2 and CALM1 expression on cancer cell viability. 50,000 of HeLa cells from the exponentially growth phase were seeded in each of the wells of a 24-well plates the day before the siRNA/apatite complexes were prepared by mixing $3 \mu \mathrm{l}$ of $1 \mathrm{M}$ $\mathrm{CaCl}_{2}$ with $10 \mathrm{nM}$ of siRNA in $1 \mathrm{ml}$ of fresh serum-free $\mathrm{HCO}_{3}^{-}(44 \mathrm{mM})$-buffered DMEM medium (pH 7.5) and incubating at $37^{\circ} \mathrm{C}$ for 30 min. The medium containing the siRNA/apatite complexes supplemented with 10\% FBS had been added onto the rinsed cells before the cells were cultured consecutively for $48 \mathrm{~h}$ and the assessment on cell viability was carried out. Each experiment was done in triplicate and the data represent mean value \pm SE $(n=3)$.

compared to the free particles (positive control) was possibly due to the constitutive expression of the genes in spite of the cleavage of substantial amount of the respective mRNAs and the active roles being played by MAP kinase and PI-3 kinase pathways in cell survival or proliferation.

\section{Influences of PLCG2 and CALM1 gene knockdown on cisplatin-induced cell toxicity}

Cisplatin is one of the most effective anti-cancer drugs for solid tumors, including ovarian, testicular, cervical, and small cell lung cancers [24,25]. Treatment of HeLa cells with $1 \mu \mathrm{M}$ of cisplatin for 2 consecutive days caused $25 \%$ of cell death compared with particles only (Figure 2) and almost same level of cell death was observed for the treatment where both apatite/siRNA complexes and cisplatin were incubated together with the cells for the same period of time, suggesting an additive effect on cell death probably owing to the lack of cross-talk(s) between the pathways of $\mathrm{Ca}^{2+}$-calmodulin signaling and cisplatin-mediated toxicity.

On the contrary, the combined treatment with apatite/ anti-PLCG2 siRNA complex and a lower dose of cisplatin $(200 \mathrm{nM})$ led to the enhancement of cell viability compared with apatite/anti-PLCG2 siRNA or cisplatin (Figure 3), indicating that cisplatin at that particular dose might activate another form of PLC [26] or activate MAP kinase/PI-3 kinase signaling cascades, leading to the enhanced cell growth in the absence of PLCG2 . Silencing of PLCG2 gene promoted more cell growth than silencing of CALM1 gene at that lower dose of cisplatin probably because PLCG2 is more upstream to and therefore, more important regulator than CALM1 in $\mathrm{Ca}^{2+}$-calmodulin signaling.
Influences of PLCG2 and CALM1 gene knockdown on doxorubicin-induced cell toxicity

Doxorubicin is another chemotherapy drug widely used for the treatment of a variety of cancers including cervical cancer $[27,28]$. Doxorubicin which killed almost $50 \%$ of the cells at $1 \mu \mathrm{M}$ concentration of the drug (Figure 4) seems to be more potent than cisplatin which killed $25 \%$ of the cells at the same dose (Figure 2) following continuous 2 day incubation with HeLa cells. Silencing of PLCG2 gene following intracellular delivery of apatite/anti-PLCG2 siRNA, clearly sensitized the cells to doxorubicin at that particular concentration $(1 \mu \mathrm{M})$ killing more than $60 \%$ of the cells due to the synergistic effect of the drug and the gene knockdown. This could be due to the activation of $\mathrm{Ca}^{2+}$-calmodulin pathway [29] by doxirubicin- an effect that might have hindered the cytotoxic effect of doxorubicin and therefore, targeted cleavage of PLC mRNA or to some extent calmodulin 1 mRNA resulted in blocking of the Ca-calmodulin pathway and inhibition of cell growth or proliferation (Figure 4), thus synergistically enhancing the cancer cell apoptosis in presence of doxorubicin.

Similar finding was observed after intracellular delivery of anti-PLCG2 siRNA and $200 \mathrm{nM}$ of doxorubicin, whereas delivery of anti-CALM1 siRNA did not result in a synergistic effect in combination with doxorubicin (200 nM) (Figure 5) probably because of CALM1 location more downstream to PLCG2 in the pathway.

\section{Influences of PLCG2 and CALM1 gene knockdown on paclitaxel-induced cell toxicity}

Paclitaxel as a microtubule stabilizer is used for the treatment for various cancers including cervical cancer in combination with cisplatin and other cancer drug(s) $[30,31]$. As shown in Figures 6, $1 \mu \mathrm{M}$ paclitaxel when 


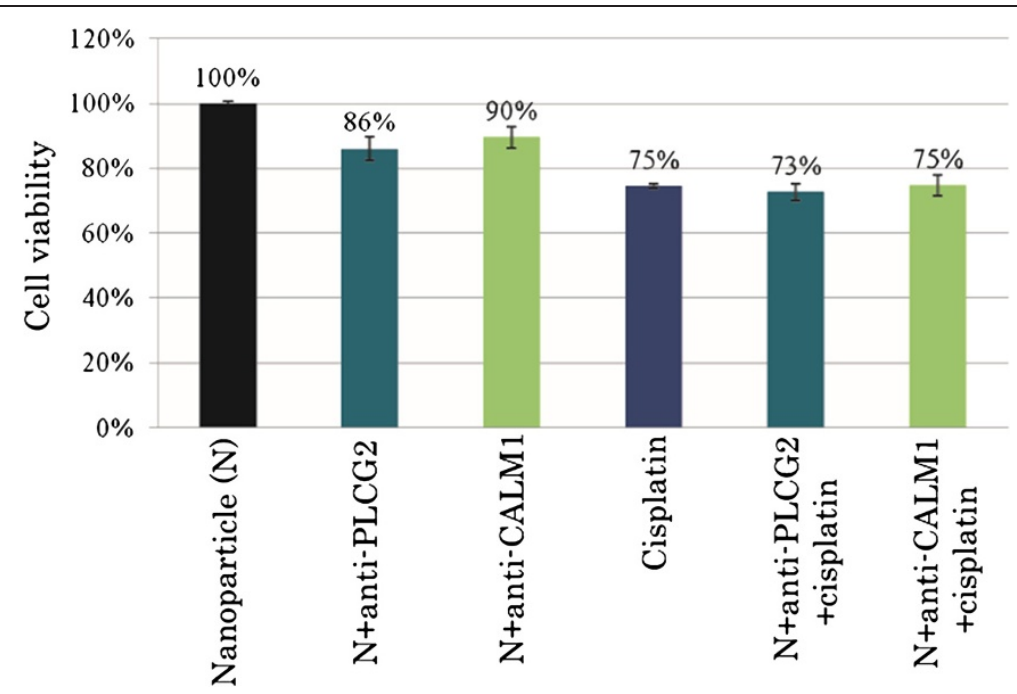

Figure 2 Effects of silencing of PLCG2 and CALM1 expression on viability of cancer cells under higher dose of cisplatin. 50,000 of HeLa cells from the exponentially growth phase were seeded in each of the wells of a 24-well plates the day before the siRNA/apatite complexes were prepared by mixing $3 \mu \mathrm{l}$ of $1 \mathrm{M} \mathrm{CaCl}_{2}$ with $10 \mathrm{nM}$ of siRNA in $1 \mathrm{ml}$ of fresh serum-free $\mathrm{HCO}_{3}^{-}(44 \mathrm{mM}$ )-buffered DMEM medium (pH 7.5) and incubating at $37^{\circ} \mathrm{C}$ for $30 \mathrm{~min}$. The medium containing the siRNA/apatite complexes supplemented with $10 \%$ FBS had been added onto the rinsed cells either with or without $1 \mu \mathrm{M}$ of cisplatin before the cells were cultured consecutively for $48 \mathrm{~h}$ and the assessment on cell viability was carried out. Each experiment was done in triplicate and the data represent mean value $\pm \operatorname{SE}(n=3)$.

incubated with HeLa cells continuously for 2 days, caused more than $70 \%$ of the cells to death, indicating that paclitaxel is the most effective of the 3 drugs used in the study. However, the combined treatment of the apatite/siRNA complexes possessing either anti-PLCG2 or anti-CALM1 siRNA and paclitaxel $(1 \mu \mathrm{M})$ resulted in reduction of the total cell death by almost $10 \%$. The could be explained by the notion that silencing of the
PLCG2 and CALM1 genes ends up with the downregulation of $\mathrm{Ca}^{2+} / \mathrm{calmodulin}$ signaling and the decline in the level of $\mathrm{Ca}^{2+} /$ calmodulin-dependent protein kinases (CaMKs). Since CAMKs regulate microtubule dynamics by phosphorylation of the microtubule regulator stathmin [32], the overall effect of gene knockdown might cause disruption of microtubule dynamics, thus preventing paclitaxel to stabilize all of the microtubules

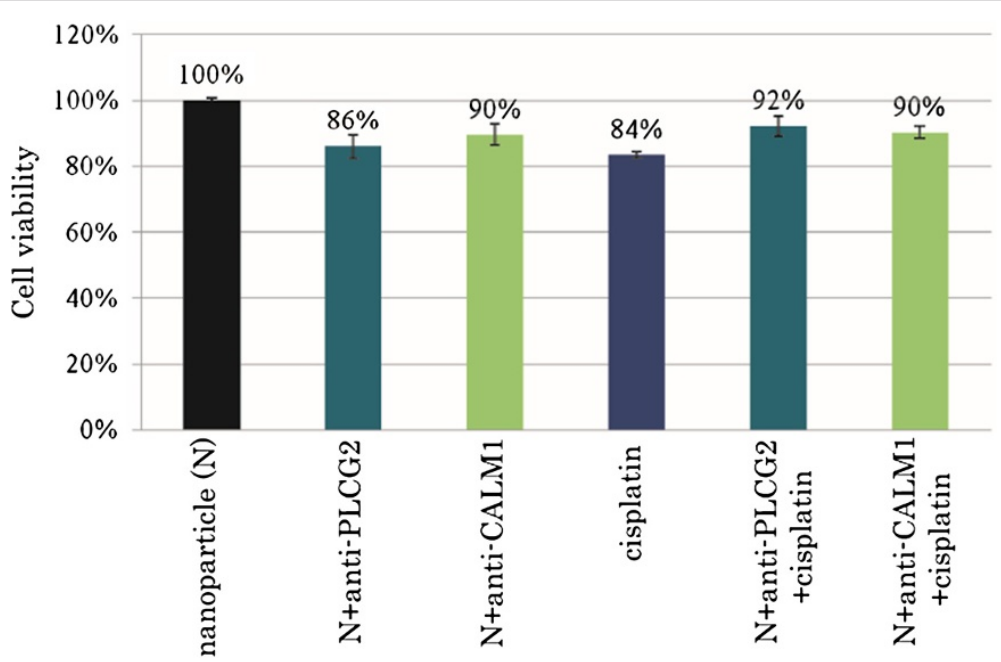

Figure 3 Effects of silencing of PLCG2 and CALM1 expression on viability of cancer cells under lower dose of cisplatin. 50,000 of HeLa cells from the exponentially growth phase were seeded in each of the wells of a 24-well plates the day before the siRNA/apatite complexes were prepared by mixing $3 \mu \mathrm{l}$ of $1 \mathrm{M} \mathrm{CaCl}_{2}$ with $10 \mathrm{nM}$ of siRNA in $1 \mathrm{ml}$ of fresh serum-free $\mathrm{HCO}_{3}^{-}(44 \mathrm{mM})$-buffered DMEM medium (pH 7.5) and incubating at $37^{\circ} \mathrm{C}$ for $30 \mathrm{~min}$. The medium containing the siRNA/apatite complexes supplemented with 10\% FBS had been added onto the rinsed cells either with or without $200 \mathrm{nM}$ of cisplatin before the cells were cultured consecutively for $48 \mathrm{~h}$ and the assessment on cell viability was carried out. Each experiment was done in triplicate and the data represent mean value $\pm \operatorname{SE}(n=3)$. 


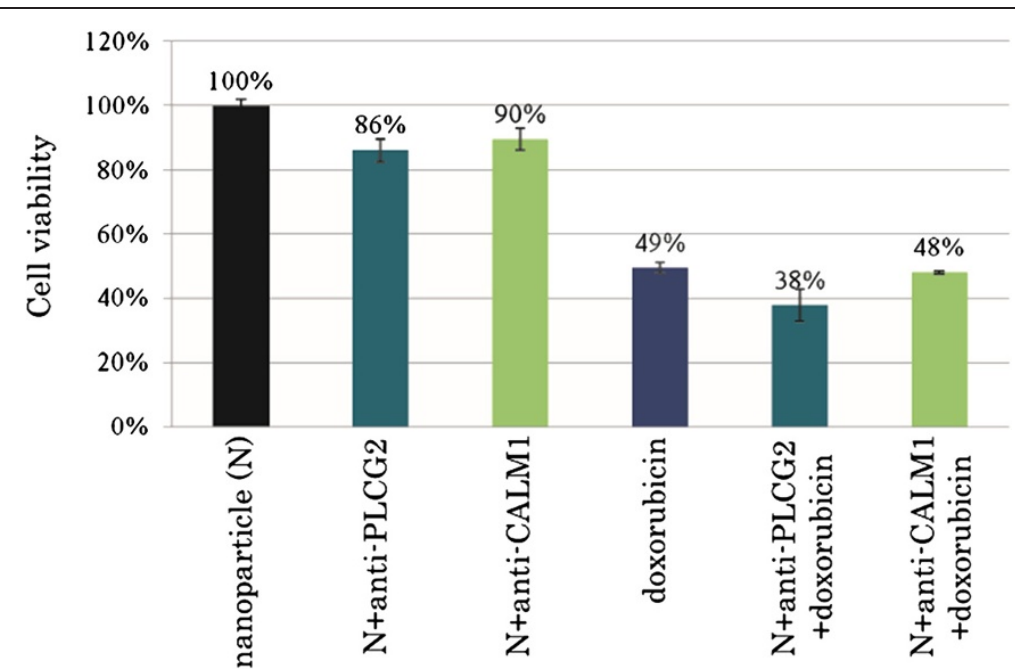

Figure 4 Effects of silencing of PLCG2 and CALM1 expression on viability of cancer cells under higher dose of doxorubicin. 50,000 of HeLa cells from the exponentially growth phase were seeded in each of the wells of a 24-well plates the day before the siRNA/apatite complexes were prepared by mixing $3 \mu \mathrm{l}$ of $1 \mathrm{M} \mathrm{CaCl}_{2}$ with $10 \mathrm{nM}$ of siRNA in $1 \mathrm{ml}$ of fresh serum-free $\mathrm{HCO}_{3}^{-}(44 \mathrm{mM}$ )-buffered DMEM medium (pH 7.5) and incubating at $37^{\circ} \mathrm{C}$ for $30 \mathrm{~min}$. The medium containing the siRNA/apatite complexes supplemented with $10 \%$ FBS had been added onto the rinsed cells either with or without $1 \mu \mathrm{M}$ of doxorubicin before the cells were cultured consecutively for $48 \mathrm{~h}$ and the assessment on cell viability was carried out. Each experiment was done in triplicate and the data represent mean value $\pm \operatorname{SE}(n=3)$.

and more effectively arrest the cell cycle for induction of apoptosis at that relatively higher concentration of the drug.

On the contrary, when the concentration of paclitaxel was lowered to $200 \mathrm{nM}$, silencing of PLCG2 or CALM1 gene expression was associated with a robust decrease in cell viability demonstrating a synergistic effect of the drug action and the gene knockdown on cell proliferation or survival (Figure 7). Since $\mathrm{Ca}^{2+} / \mathrm{CaM}$ promotes cell proliferation by facilitating $G_{2} / M$ transition, $M$ phase progression, and exit from mitosis [15] while microtubules induces apoptosis by arresting G2/M phase [33], silencing of either PLCG2 or CALM1 gene in presence of paclitaxel resulted in complete arrest of the cell cycle.

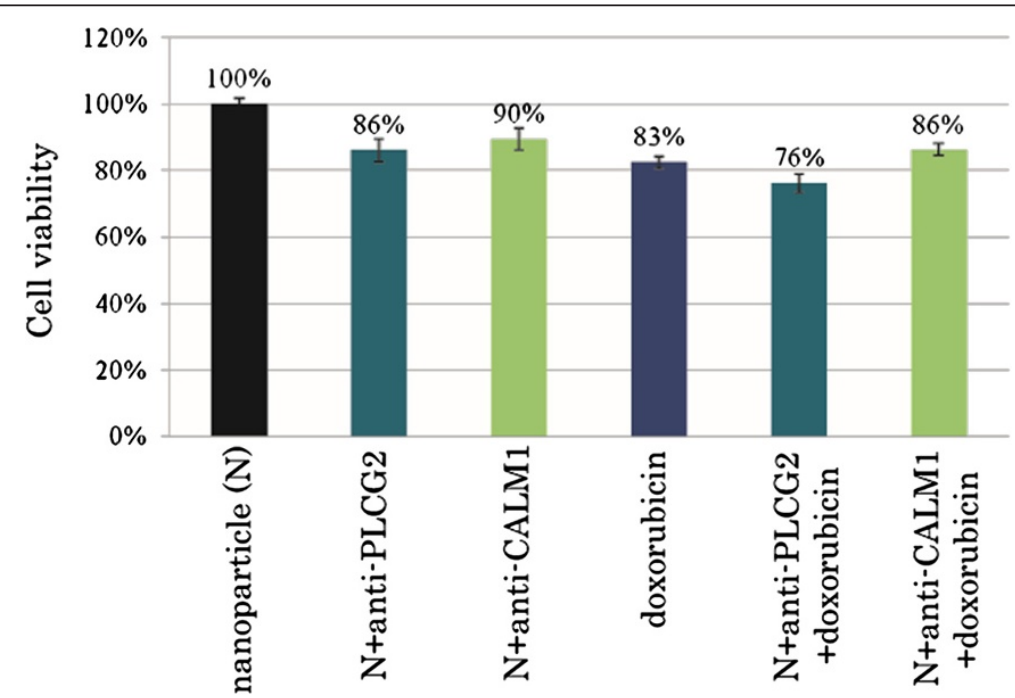

Figure 5 Effects of silencing of PLCG2 and CALM1 expression on viability of cancer cells under lower dose of doxorubicin. 50,000 of HeLa cells from the exponentially growth phase were seeded in each of the wells of a 24-well plates the day before the siRNA/apatite complexes were prepared by mixing $3 \mu \mathrm{l}$ of $1 \mathrm{M} \mathrm{CaCl}_{2}$ with $10 \mathrm{nM}$ of siRNA in $1 \mathrm{ml}$ of fresh serum-free $\mathrm{HCO}_{3}^{-}(44 \mathrm{mM}$ )-buffered DMEM medium (pH 7.5) and incubating at $37^{\circ} \mathrm{C}$ for $30 \mathrm{~min}$. The medium containing the siRNA/apatite complexes supplemented with $10 \%$ FBS had been added onto the rinsed cells either with or without $200 \mathrm{nM}$ of doxorubicin before the cells were cultured consecutively for $48 \mathrm{~h}$ and the assessment on cell viability was carried out. Each experiment was done in triplicate and the data represent mean value $\pm S E(n=3)$. 


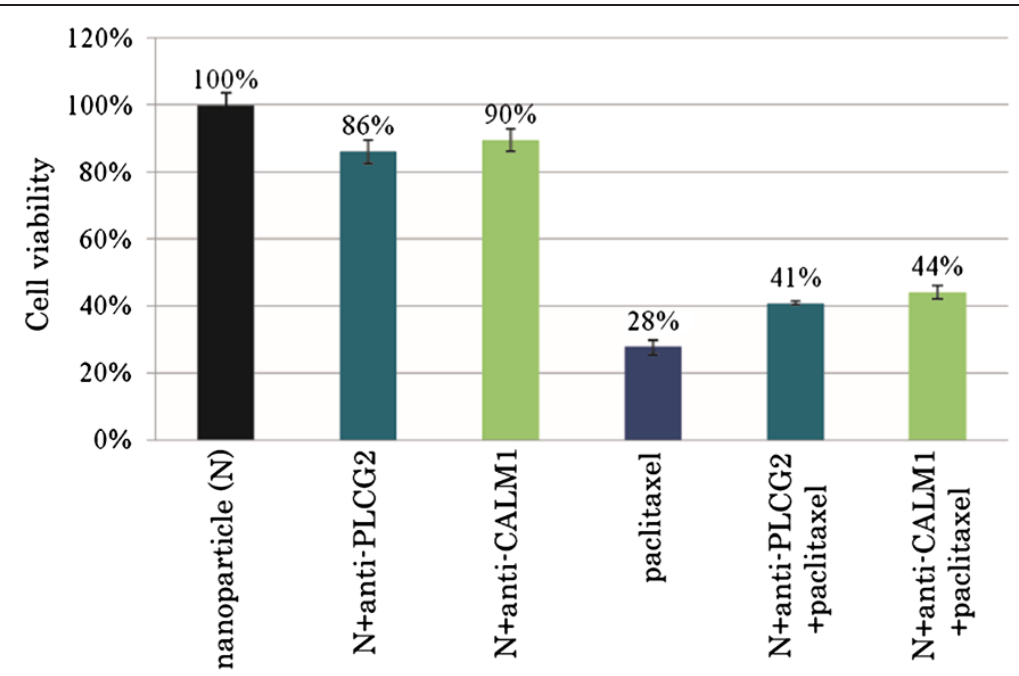

Figure 6 Effects of silencing of PLCG2 and CALM1 expression on viability of cancer cells under higher dose of paclitaxel. 50,000 of HeLa cells from the exponentially growth phase were seeded in each of the wells of a 24-well plates the day before the siRNA/apatite complexes were prepared by mixing $3 \mu \mathrm{l}$ of $1 \mathrm{M} \mathrm{CaCl}_{2}$ with $10 \mathrm{nM}$ of siRNA in $1 \mathrm{ml}$ of fresh serum-free $\mathrm{HCO}_{3}^{-}(44 \mathrm{mM}$ )-buffered DMEM medium (pH 7.5) and incubating at $37^{\circ} \mathrm{C}$ for $30 \mathrm{~min}$. The medium containing the siRNA/apatite complexes supplemented with 10\% FBS had been added onto the rinsed cells either with or without $1 \mu \mathrm{M}$ of paclitaxel before the cells were cultured consecutively for $48 \mathrm{~h}$ and the assessment on cell viability was carried out. Each experiment was done in triplicate and the data represent mean value $\pm \operatorname{SE}(n=3)$.

\section{Conclusions}

PLCG2 and CALM1 of $\mathrm{Ca}^{2+}$-calmodulin signalling pathways are the two potential targets for gene knockdown in doxorubicin and paclitaxel-based chemotherapy of cervical cancer. Therefore, pre-clinical study in animal models of cervical cancer should be carried out through tumor-targeted delivery of anti-PLCG2 or CALM1 siRNA in combination with passively diffusible anti-cancer drugs.

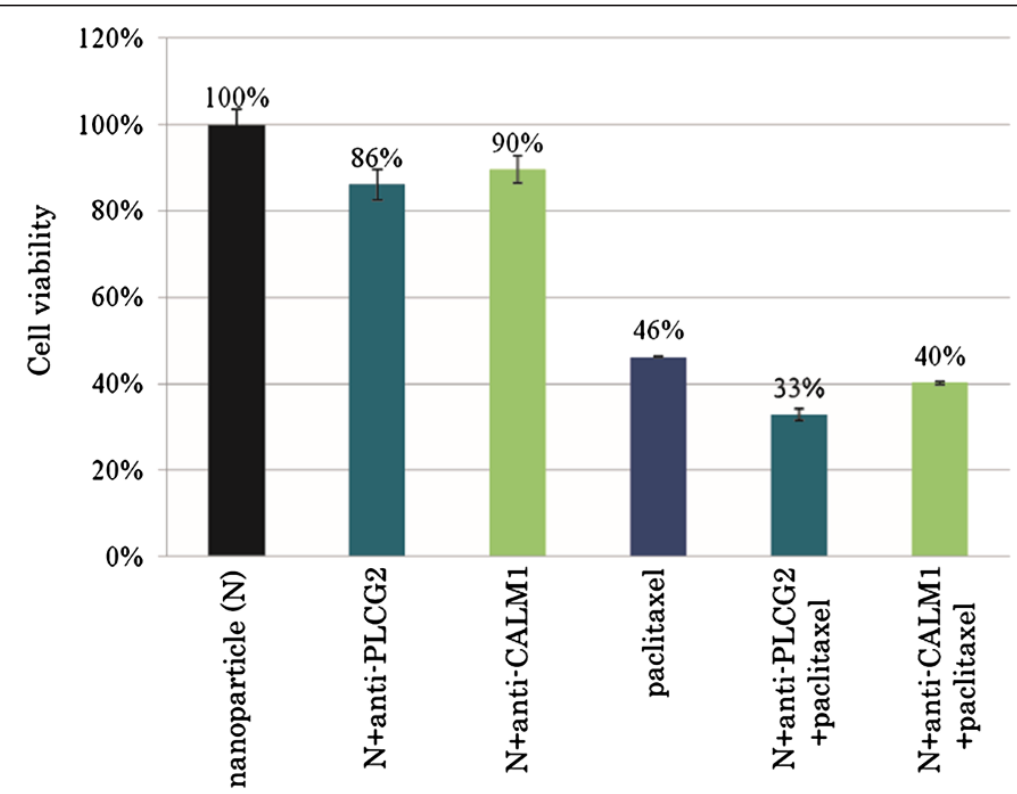

Figure 7 Effects of silencing of PLCG2 and CALM1 expression on viability of cancer cells under lower dose of paclitaxel. 50,000 of HeLa cells from the exponentially growth phase were seeded in each of the wells of a 24-well plates the day before the siRNA/apatite complexes were prepared by mixing $3 \mu \mathrm{l}$ of $1 \mathrm{M} \mathrm{CaCl}_{2}$ with $10 \mathrm{nM}$ of siRNA in $1 \mathrm{ml}$ of fresh serum-free $\mathrm{HCO}_{3}^{-}(44 \mathrm{mM}$ )-buffered DMEM medium (pH 7.5) and incubating at $37^{\circ} \mathrm{C}$ for $30 \mathrm{~min}$. The medium containing the siRNA/apatite complexes supplemented with $10 \%$ FBS had been added onto the rinsed cells either with or without $200 \mathrm{nM}$ of doxorubicin before the cells were cultured consecutively for $48 \mathrm{~h}$ and the assessment on cell viability was carried out. Each experiment was done in triplicate and the data represent mean value $\pm S E(n=3)$. 


\section{Methods Reagents}

MTT (3-(4,5-Dimethylthiazol-2-yl) -2,5-diphenyl tetrazolium bromide) and DMEM were purchased from Molecular Probes, Sigma and Gibco BRL, respectively. Validated siRNAs against PLCG2 (Target sequenc 5'GACGACGGTTGTGAATGATAA-3') and CALM1(Target sequence 5'-CGGCAACTTACACACATTGAA-3') were obtained from Qiagen. Upon delivery in the lyophilized form, the siRNAs were diluted to obtain a $20 \mu \mathrm{M}$ solution using RNAse-free water and allocated into multiple reaction tubes for storage at $-20^{\circ} \mathrm{C}$ as repeated thawing might affect siRNA's silencing efficiency.

\section{Cell culture}

HeLa cells were cultured in $25-\mathrm{cm}^{2}$ flasks in Dulbecco's modified Eagle's medium (DMEM, Gibco BRL) supplemented with $10 \%$ fetal bovine serum (FBS), $50 \mu \mathrm{g}$ penicillin $\mathrm{ml}-1,50 \mu \mathrm{g}$ streptomycin $\mathrm{ml}-1$ and $100 \mathrm{\mu g}$ neomycin ml- 1 at $37^{\circ} \mathrm{C}$ in a humidified $5 \% \mathrm{CO}_{2}$ containing atmosphere.

\section{Formation of siRNA/carbonate apatite complexes and transfection of cells}

Cells from the exponentially growth phase were seeded at 50,000 cells per well into 24-well plates the day before transfection. $3 \mu \mathrm{l}$ of $1 \mathrm{M} \mathrm{CaCl}_{2}$ was mixed with $10 \mathrm{nM}$ of siRNA in $1 \mathrm{ml}$ of fresh serum-free $\mathrm{HCO}_{3}^{-}(44 \mathrm{mM})$ buffered DMEM medium ( $\mathrm{pH}$ 7.5), followed by incubation at $37{ }^{\circ} \mathrm{C}$ for $30 \mathrm{~min}$ for complete generation of siRNA/carbonate apatite particles [18,19]. 10\% FBS and (depending on the experimental conditions) 0.2 to $1 \mu \mathrm{M}$ drugs (cisplatin, doxorubicin, paclitaxel) had been mixed with the medium containing the siRNA/apatite complexes before the medium was added onto the rinsed cells. The cells were subsequently cultured for $48 \mathrm{~h}$ prior to the assessment on cell viability $[18,19]$.

\section{Cell viability assessment with MTT assay}

$30 \mu \mathrm{l}$ of MTT solution $(5 \mathrm{mg} / \mathrm{ml})$ was added onto the cells in each well of the 24-well plate and incubated for $4 \mathrm{hr}$ at $37^{\circ} \mathrm{C}$. $0.5 \mathrm{ml}$ of DMSO was added after removal of the medium from each well to resolve the crystals, followed by incubation for $5 \mathrm{~min}$ at $37^{\circ} \mathrm{C}$. Absorbance was measured in a micro plate reader at $570 \mathrm{~nm}$ with a reference wavelength of $630 \mathrm{~nm}$. Each experiment was done in triplicate with the data representing mean value \pm SE $(n=3)$ and being statistically significant $(<0.05)$.

\section{Abbreviations}

PLCG2: PLC-gamma-2; CALM1: Calmodulin 1; PIP2: Phosphatidylinositol 4, 5 bisphosphate; DAG: Diacylglycerol; IP3: Inositol $(1,4,5)$ trisphosphate; CaM: Calmodulin; PLC: Phospholipase C; DMEM: Dulbecco's Modified Eagle's Medium; RNAi: RNA interference; siRNA: Small interfering RNA; shRNA: Short hairpin RNA; FBS: Fetal bovine serum; MTT: (3-(4,5-Dimethylthiazol-2-yl) -2,5diphenyl tetrazolium bromide).

\section{Competing interests}

The authors declare that they have no competing interests.

\section{Acknowledgements}

This work has financially been supported by a research grant (Project ID 0202-09-SF0013) of the Ministry of Science, Technology and Innovation (MOSTI), Malaysia.

\section{Author details}

${ }^{1}$ Faculty of Medicine and Health Science, International Medical University (IMU), No. 126, Jalan 19/155B, Bukit Jalil, Kuala Lumpur 57000, Malaysia. 2Jeffrey Cheah School of Medicine and Health Sciences, Monash University Sunway Campus, Jalan Lagoon Selatan, Bandar Sunway, Selangor Darul Ehsan, Malaysia. ${ }^{3}$ Department of Biomolecular Engineering, Graduate School of Bioscience and Biotechnology, Tokyo Institute of Technology, 4259 Nagatsuta-cho, Midori-ku, Yokohama 226-8501, Japan.

\section{Authors' contributions}

AS has originally planned the project in close discussion with EHC and TA and finally carried out the experiments in collaborations with MJC, APK and $\mathrm{SH}$. All authors read and approved the final manuscript.

Received: 30 January 2012 Accepted: 18 June 2012

Published: 18 June 2012

\section{References}

1. de Fougerolles AR: Delivery vehicles for small interfering RNA in vivo. Hum Gene Ther 2008, 19:125-132.

2. Gao K, Huang L: Nonviral methods for siRNA delivery. Mol Pharm 2009, 6:651-658.

3. Lee NS, Rossi JJ: Control of HIV-1 replication by RNA interference. Virus Res 2004, 102:53-58.

4. Grünweller A, Hartmann RK: RNA interference as a gene-specific approach for molecular medicine. Curr Med Chem 2005, 12:3143-3161.

5. Ito M, Kawano K, Miyagishi M, Taira K: Genome-wide application of RNAi to the discovery of potential drug targets. FEBS Lett 2005, 579:5988-5995.

6. Lu PY, Xie F, Woodle MC: In vivo application of RNA interference: from functional genomics to therapeutics. Adv Genet 2005, 54:117-142.

7. Chowdhury EH: Nuclear targeting of viral and non-viral DNA. Expert Opin Drug Deliv 2009, 6:697-703.

8. Chowdhury EH: Strategies for tumor-directed delivery of siRNA. Expert Opin Drug Deliv 2011, 8:389-401.

9. Reischl D, Zimmer A: Drug delivery of siRNA therapeutics: potentials and limits of nanosystems. Nanomedicine 2009, 5:8-20.

10. Ryther RC, Flynt AS, Phillips JA, Patton JG: siRNA therapeutics: big potential from small RNAs. Gene Ther 2005, 12:5-11.

11. van de Water FM, Boerman OC, Wouterse AC, Peters JG, Russel FG, Masereeuw R: Intravenously administered short interfering RNA accumulates in the kidney and selectively suppresses gene function in renal proximal tubules. Drug Metab Dispos 2006, 34:1393-1397.

12. Dickerson EB, Blackburn WH, Smith MH, Kapa LB, Lyon LA, McDonald JF: Chemosensitization of cancer cells by siRNA using targeted nanogel delivery. BMC Cancer 2010, 10:1-11

13. Roberts PJ, Der CJ: Targeting the Raf-MEK-ERK mitogen-activated protein kinase cascade for the treatment of cancer. Oncogene 2007, 26:32913310.

14. Brader S, Eccles SA: Phosphoinositide 3-kinase signalling pathways in tumor progression, invasion and angiogenesis. Tumori 2004, 90:2-8.

15. Kahl CR, Means AR: Regulation of cell cycle progression by calcium/ calmodulin-dependent pathways. Endocr Rev 2003, 24:719-6.

16. Clapham DE: Calcium Signaling. Cell 2007, 131:1047-1058.

17. Colomer J, Means AR: Physiological roles of the Ca2+/CaM-dependent protein kinase cascade in health and disease. Subcell Biochem 2007, 45:169-214.

18. Hossain S, Stanislaus A, Chua MJ, Tada S, Tagawa Y, Chowdhury EH, Akaike T: Carbonate apatite-facilitated intracellularly delivered siRNA for efficient knockdown of functional genes. J Control Release 2010, 147:101-108. 
19. Stanislaus A, Hossain S, Chua MJ, Kunnath AP, Wen QC, Syakira SN, Siong GY, Loong SW, Othman I, Akaike T, Chowdhury EH: Fabrication and intracellular delivery of siRNA/carbonate apatite nano-composites for effective knockdown of cyclin B1 gene. Drugs Therp Studies 2011, 1:26-30.

20. Cowell CF, Döppler H, Yan IK, Hausser A, Umezawa Y, Storz P: Mitochondrial diacylglycerol initiates protein-kinase-D1-mediated ROS signalling. J Cell Sci 2009, 122:919-928.

21. Kim M, Jung J, Lee K: Roles of ERK, PI3 kinase, and PLC- - pathways induced by overexpression of translationally controlled tumor protein in HeLa cells. Arch Biochem Biophys 2009, 485:82-87.

22. Li CJ, Heim R, Lu P, Pu Y, Tsien RY, Chang DC: Dynamic redistribution of calmodulin in HeLa cells during cell division as revealed by a GFPcalmodulin fusion protein technique. J Cell Sci 1999, 112:1567-1577.

23. Jang MK, Goo YH, Sohn YC, Kim YS, Lee SK, Kang H, Cheong J, Lee JW: $\mathrm{Ca} 2+/$ calmodulin-dependent protein kinase IV stimulates nuclear factor-kappa B transactivation via phosphorylation of the p65 subunit. J Biol Chem 2001, 276:20005-20010

24. Eastman A: Activation of programmed cell death by anticancer agents: cisplatin as a model system. Cancer Cell 1990, 2:275-279.

25. Alberts DS, Garcia D, Mason-Liddil N: Cisplatin in advanced cancer of the cervix: an update. Semin Oncol 1991, 18:11-24.

26. Nishio K, Sugimoto Y, Fujiwara Y, Ohmori T, Morikage T, Takeda Y, Ohata M, Saijo N: Phospholipase C-mediated hydrolysis of phosphatidylcholine is activated by cis-diamminedichloroplatinum(II). J Clin Invest 1992, 89:16221628.

27. Kristensen G, Tropé C: Endometrial cancer: the management of high-risk disease. Curr Oncol Rep 2004, 6:471-475.

28. Nguyen HN, Nordqvist SR: Chemotherapy of advanced and recurrent cervical carcinoma. Semin Surg Oncol 1999, 16:247-250.

29. Thompson MG, Hickman JA: Doxorubicin interactions at the membrane: evidence for a biphasic modulation of inositol lipid metabolism. Eur J Cancer 1991, 27:1263-1268.

30. De Vincenzo R, Amadio G, Ricci C, Licameli A, Ferrandina G, Capelli G, Scambia G: Treatment of cervical cancer in Italy: strategies and their impact on the women. Vaccine 2009, 27:A39-A45.

31. Pectasides D, Kamposioras K, Papaxoinis G, Pectasides E: Chemotherapy for recurrent cervical cancer. Cancer Treat Rev 2008, 34:603-613.

32. Melander Gradin H, Marklund U, Larsson N, Chatila TA, Gullberg M: Regulation of microtubule dynamics by $\mathrm{Ca} 2+/ \mathrm{Calmodulin}$-dependent kinase IV/Gr-dependent phosphorylation of oncoprotein 18. Mo/ Cell Biol 1997, 17:3459-3467.

33. Gallagher BM: Microtubule-stabilizing natural products as promising cancer therapeutics. Curr Med Chem 2007, 14:2959-2967.

doi:10.1186/1475-2867-12-30

Cite this article as: Stanislaus et al.: Knockdown of PLC-gamma-2 and calmodulin 1 genes sensitizes human cervical adenocarcinoma cells to doxorubicin and paclitaxel. Cancer Cell International 2012 12:30.

\section{Submit your next manuscript to BioMed Central and take full advantage of:}

- Convenient online submission

- Thorough peer review

- No space constraints or color figure charges

- Immediate publication on acceptance

- Inclusion in PubMed, CAS, Scopus and Google Scholar

- Research which is freely available for redistribution 